\title{
Scaling up of Green Gram Production under Front-Line Demonstrations in Jodhpur District of Western Rajasthan, India
}

\author{
Manmohan Puniya' ${ }^{1}$, M. S. Chandawat ${ }^{1}$, Gajanand Nagal ${ }^{1}$, \\ R. Jeetarwal ${ }^{1}$, B. C. Ola ${ }^{1}$ and Arvind Kumar ${ }^{2 *}$ \\ ${ }^{1}$ Krishi Vigyan Kendra, Phalodi, JodhpurII, Agricultural University, Jodhpur342301 \\ ${ }^{2}$ ICAR-NASF, Pusa Campus, New Delhi-110012, India \\ *Corresponding author
}

\begin{tabular}{|l|}
\hline K e y w or d s \\
Adoption, Frontline \\
demonstrations, \\
Greengram, \\
Productivity, \\
Profitability \\
\hline Article Info \\
\hline $\begin{array}{l}\text { Accepted: } \\
\text { 15 December } 2019 \\
\text { Available Online: } \\
\text { 20 January 2020 }\end{array}$ \\
\hline
\end{tabular}

\section{A B S T R A C T}

\section{Introduction}

Pulses are the major source of dietary protein for the majority of population in our country.
Besides being the source of protein, pulses contribute substantially to food production system by enriching the soil through biological nitrogen fixation and improving 
soil physical conditions. Though pulses are consumed all over the world, its consumption is higher in those parts of the world where animal protein are scarce and expensive (Ofuya and Akhidue, 2005). Pulses are important food crop for human consumption and animal feed. Being leguminous in nature, they are considered to be important components of cropping system because of their viability to fix atmospheric nitrogen, add substantial amounts of organic matter to the soil and produce reasonable yields with low inputs under harsh climatic and soil conditions (Rakhode et al., 2011). Moongwheat cropping system is predominant andit's continuously practiced by farmers in the arid zone of Rajasthan (Dhaka et al., 2016). Greengram (Vigna radiate L. Wilczek.) is the third important pulse crop in India. It can be grown both as kharif green gram and summer green gram. With the advent of short duration, mungbean yellow mosaic virus tolerant and synchronous maturing varieties of green gram (55-60 days), there is a big opportunity for successful cultivation of green gram with wheat based rotation.

Green gram belonging to family leguminosae, is a tropical and sub-tropical grain legume, adapted to different types of soil conditions and environments (kharif, spring and summer). It ranks third in India after chickpea and pigeonpea. It has strong root system and capacity to fix the atmospheric nitrogen in to the soil and improves soil health and contributes significantly to enhancing the yield of subsequent crops(Tomar et al., 2012).Greengram yield is also affected by insects-pests and diseases, especially by greengramyellow mosaic virus (GYMV) and Cercospora leaf spot (CLS). There is a strong need to develop the lines/varieties which give outstanding and consistent performance in kharif season over diverse environment. Development of varieties with high yield and stable performance is a prime target of all green gram improvementprograms. The total production of pulses in India was 22.95 million tonnes from the area of 29.28 million hectares in the year 2015-16. Whereas in Rajasthan, the total kharif pulses production was 1.8 million tonnes from the area of 4.23 million hectaresin 2017-18. The green gram production among kharif pulses was 0.97 million tons from the area of 2.24 million hectares in Rajasthan in the year 2017-18. Jodhpur district stands second rank in terms of area and production of green gram in the state. In this district, the green gram crop is grown in an area of 3.18 lacs ha with an annual production of over 1.92lacs tons (GOR, 2017-18). The front line demonstration is an important method of transferring the latest package of practices in totality to farmers. By which, farmers learn latest technologies of oilseeds and pulses production under real farming situation at his own field. Further, these demonstrations are designed carefully where provisions are made for speedy dissemination of demonstrated technology among farming community through organization of other supportive extension activities, such as field days and farmers convention. The main objective of the Front Line Demonstration is to demonstrate newly released crop production and protection technologies and management practices at the farmers' field under different ago-climatic regions and farming situations. While demonstrating the technologies at the farmer's field, the scientists are required to study, the factors contributing to higher crop production, field constraints of production and thereby generating production factor and feed-back information. Front Line Demonstrations are conducted in a block of ten hectares of land in order to have better impact of the demonstrated technology on the farmers and field level extension functionaries with full package of practices. Keeping in view the present study was done to analyze the performance and to promote the Front Line 
Demonstration (FLD) on green gram production.

\section{Materials and Methods}

Present study was conducted on FLD green gram in rainfed condition in Jodhpur district of Rajasthan. Total 100 frontline demonstrations were conducted at farmers' field in villages of Palli-phanta, Bendo ka bera, Padasla and Kali-mali of Jodhpur district of Rajasthan, during kharif season 2018 and 2019. Each demonstration was conducted on an area of 0.4 ha, adjacent-to the demonstration plot was kept as farmers' practices. The package of improved technologies like line sowing, nutrient management, seed treatment and whole package were used in the demonstrations. The variety of green gram'GAM-5' was inincluded in demonstrations methods used for the present study with respect to FLDs and farmers' practices are given in Table 1. In case of local check plots, existing practices being used by farmers were followed. In general, soils of the area under study were loamy fine to coarse and medium to low in fertility status. The spacing was $30 \mathrm{~cm}$ between rows and $10 \mathrm{~cm}$ between plants in the rows. The thinning and weeding was done invariably 35 40 days after sowing to ensure recommended plant spacing $(10 \mathrm{~cm})$ within a row $(30 \mathrm{~cm})$ because excess population adversely affects growth and yield of crop. Seed sowing was done in the first week of July, with a seed rate of $20 \mathrm{~kg} / \mathrm{ha}$. Other management practices were applied as per the package of practices for kharif crops by Department of Agriculture, Agro-climatic Zone Ia - Arid Western Plains Zone (DOA, 2018). Data with respect to grain yield from FLD plots and from fields cultivated following local practices adopted by the farmers of the area were collected and evaluated. Potential yield was taken in to consideration on the basis of standard plant population (404440 plants/ha) and average yield per plant $22.5 \mathrm{gm} / \mathrm{plant}$ under recommended package of practices with $30 \times 10 \mathrm{~cm}$ crop geometry (Chandra, 2010). Different parameters as suggested by Yadav et al., (2004) was used for gap analysis, technology index and calculating the economics parameters of green gram. The details of different parameters and formula adopted for analysis are as under:

Extension gap $=$ Demonstration yield farmers' practice yield

Technology gap = Potential yield demonstration yield

Technology index = Potential yield demonstration yield/potential yield x 100

Additional cost (Rs.) $=$ Demonstration cost (Rs.) - farmers' Practice Cost (Rs.)

Effective gain $=$ Additional returns (Rs.)additional cost (Rs.)

Additional returns $=$ Demonstration returns (Rs.)-farmers' practice returns (Rs.)

$\mathrm{B}: \mathrm{C}$ ratio $=$ Gross returns $/$ gross Cost

\section{Results and Discussion}

\section{Yield attributing traits}

The numbers of productive pods per plant under improved technology were 28.2 and 29.9 as against local check (farmers' practices), 22.7 and 23.2 pods per plants (Table 2) during the year 2018 and 2019, respectively. There was an increase of 24.22 and $28.87 \%$ in number of productive pods under demonstration of improved technology over farmers' practice. The average number of productive pods per plant in improved technology was 29.05 and as compared 22.9 under farmers' practice (local check), thus 
there were $26.5 \%$ more pods per plant under improved technology demonstrations. The numbers of seeds per pods under improved technology were 9.7 and 10.8 as against local check (farmers' practices), 6.1 and 6.9seeds per pods (Table 2) during the year 2018 and 2019, respectively. The findings confirm with the findings of Yadav et al., (2007) and Meena et al., (2011) and Meena and Singh (2017) who found more yield in pulses under FLD plots.

\section{Seed yield (kg/ha)}

The productivity of green gram under improved production technology ranged between $900-910 \mathrm{~kg} / \mathrm{ha}$ with mean yields of $905 \mathrm{~kg} / \mathrm{ha}$ and overall production $1810 \mathrm{~kg} / \mathrm{ha}$ in two years (Table 3). The productivity under improved technology was 900 and $910 \mathrm{~kg} / \mathrm{ha}$ during 2018 and 2019, respectively as against a yield range between 540 to $570 \mathrm{~kg} / \mathrm{ha}$ under farmers' practice. In comparison to farmer's practice, there was low than FLDplots of 66.67 and $59.64 \%$ in productivity of green gram under improved technologies in 2018 and 2019, respectively. The increased grain yield with improved technologies was mainly because of line sowing use of nutrient management and weed management. The present findings confirm the findings of Singh and Meena (2011), Poonia and Pithia (2011), Meena et al., (2012). Math et al., (2012), Raj el al. (2013) and Meena and Singh (2017). They found more gain yield of FLD plots than the existing practices.

\section{Gap analysis}

Evaluation of findings of the study (Table 4) stated that an extension gap of 340 to 360 $\mathrm{kg} / \mathrm{ha}$ was found between demonstrated technology and farmers' practice and on average basis the extension gap was 350 $\mathrm{kg} / \mathrm{ha}$. The extension gap was highest (360 $\mathrm{kg} / \mathrm{ha}$ ) during 2018 and lowest (340 kg/ha) during 2019. Such gap might be attributed to adoption of improved technology especially high yielding variety (GAM- 5 )sown with the help of seed cum fertilizers drill with balanced nutrition, weed management and appropriate plant protection measures in demonstrations which resulted in higher grain yield than the traditional farmers' practices. The study further exhibited a wide technology gap during different years. It was lowest (890 $\mathrm{kg} / \mathrm{ha}$ ) during 2019 and highest (900 kg/ha) during 2018. The average technology gap of both the years was $895 \mathrm{~kg} / \mathrm{ha}$. The difference in technology gap in different years is due to better performance of recommended varieties with different interventions and more feasibility of recommended technologies during the course of study. Similarly, the technology index for all demonstrations in the study was in accordance with technology gap. Higher technology index reflected the inadequate transfer of proven technology to growers and insufficient extension services for transfer of technology. On the basis of two years study, overall $49.7 \%$ technical index was recorded, which was lowest $(49.4 \%)$ during 2019 and highest (50 \%) during 2018.Hence, it can be inferred that the awareness and adoption of improved varieties with recommended scientific package of practices have increased during the advancement of study period. These findings are in the conformity of the results of study carried out by Chandra (2010), Meena and Singh (2016), Meena and Singh (2017), Singh and Chauhan (2010), Dayanand et al., (2012), Meenaet al., (2012) and Rajni et al., (2014).

\section{Economics}

Different variables like seed, fertilizers, biofertilizers and pesticides were considered as cash input for the demonstrations as well as farmers practice and on an average additional investment of Rs. 2155 per ha was made under demonstrations. Economic returns as a 
function of gain yield and Minimum Support Price (MSP) sale price varied during different years. The maximum returns (Rs. 42160) during the year 2019 were obtained due to high grain yield and higher MSP sale rates as declared by GOI. The higher additional returns and effective gain obtained under demonstrations could be due to improved technology, non-monetary factors, timely operations of crop cultivation and scientific monitoring. The lowest and highest benefit cost ratio (BCR) were 2.9 and 2.7 in 2019 and 2018, respectively (Table 5) depends on produced grain yield and MSP sale rates. Overall average BCR was found 2.8. The results confirm with the findings of front line demonstrations on pulses by Yadav et al., (2004), Gauttam et al., (2011), Lothwal (2010), Chaudhary (2011), Dayananda et al., (2012), Meena and Dudi (2012) and Meena and Singh (2017).

Table.1 Package of practices followed by farmers under front-line demonstrations

\begin{tabular}{|l|l|l|}
\hline Particulars & Technology interventions & Farmer's practices \\
\hline Variety & GAM-5 & Local cultivar \\
\hline Seed rate & $20 \mathrm{~kg} / \mathrm{ha}$ & $16 \mathrm{~kg} / \mathrm{ha}$ \\
\hline Soil treatment & $\begin{array}{l}\text { Trichoderma @ 2.5 kg/ha cultured with } \\
100 \mathrm{~kg} \text { FYM }\end{array}$ & No use \\
\hline Seed treatment & Carbendazim $50 \mathrm{WP} @ 2.0 \mathrm{~g} / \mathrm{kg}$ Seed & No seed treatment \\
\hline Time of sowing & First week of July & Second week of July \\
\hline $\begin{array}{l}\text { Method of sowing } \\
\text { Fertilizer } \\
\text { management }\end{array}$ & $\begin{array}{l}\text { Line sowing, } 30 \mathrm{~cm} \times 10-15 \mathrm{~cm} \\
\text { Broadcasting }\end{array}$ \\
\hline Weed management & $\begin{array}{l}15: 40: 0 \text { NPK kg/ha) } \\
\text { Early post emergence application of } \\
\text { imazethapyr } 10 \text { SL 500 ml/ha followed } \\
\text { by manual weeding at 35-40 DAS }\end{array}$ & $\begin{array}{l}\text { Use of urea } 50 \mathrm{~kg} / \mathrm{ha} \text { and } \\
\text { DAP } 150 \mathrm{~kg} / \mathrm{ha}\end{array}$ \\
\hline Water management & $\begin{array}{l}\text { Light irrigation at flowering and pod } \\
\text { formation stage }\end{array}$ & No use \\
\hline Plant protection & $\begin{array}{l}\text { Sucking pests-dimethoate 30 EC @ 1 } \\
\text { lit./ha, imidacloprid 200 SL @ } 150 \mathrm{ml} / \mathrm{ha} \\
\text { Pod borer-quinalphos 25 EC }\end{array}$ & $\begin{array}{l}\text { Products suggested by } \\
\text { local pesticide dealers }\end{array}$ \\
\hline
\end{tabular}

Table.2 Yield attributing traits of green gram under front-line demonstrations

\begin{tabular}{|c|c|c|c|c|c|c|}
\hline Years & \multicolumn{3}{|c|}{ Number of pods/plant } & \multicolumn{3}{c|}{ Number of seeds/pod } \\
\hline & FLD's & $\begin{array}{l}\text { Local } \\
\text { check }\end{array}$ & $\begin{array}{l}\text { \% increase } \\
\text { over check }\end{array}$ & FLD's & $\begin{array}{l}\text { Local } \\
\text { check }\end{array}$ & $\begin{array}{c}\text { \% increase } \\
\text { over check }\end{array}$ \\
\hline $\mathbf{2 0 1 8}-\mathbf{1 9}$ & 28.2 & 22.7 & 24.2 & 9.7 & 6.1 & 59.0 \\
\hline $\mathbf{2 0 1 9 - 2 0}$ & 29.9 & 23.2 & 28.8 & 10.8 & 6.9 & 56.5 \\
\hline Average & 29.1 & 22.9 & 26.5 & 10.3 & 6.5 & 57.8 \\
\hline
\end{tabular}


Table.3 Technological impact of green gram variety 'GAM 5'under front-line demonstrations

\begin{tabular}{|c|c|c|c|c|c|c|c|c|}
\hline \multirow[t]{2}{*}{ Years } & \multirow[t]{2}{*}{$\begin{array}{l}\text { Area } \\
\text { (ha) }\end{array}$} & \multirow[t]{2}{*}{$\begin{array}{c}\text { No. of } \\
\text { demonstration }\end{array}$} & \multirow{2}{*}{$\begin{array}{c}\text { Potential } \\
\text { yield } \\
\text { (q/ha) }\end{array}$} & \multicolumn{3}{|c|}{$\begin{array}{l}\text { Yield under demonstration } \\
\text { (kg/ha) }\end{array}$} & \multirow{2}{*}{$\begin{array}{c}\text { Yield } \\
\text { under } \\
\text { local } \\
\text { check } \\
\text { (kg/ha) }\end{array}$} & \multirow{2}{*}{$\begin{array}{c}\text { Increase } \\
\text { in yield } \\
(\%)\end{array}$} \\
\hline & & & & Highest & Lowest & Average & & \\
\hline 2018-19 & 30 & 75 & 18 & 1180 & 620 & 900 & 540 & 66.67 \\
\hline 2019-20 & 10 & 25 & 18 & 1190 & 630 & 910 & 570 & 59.64 \\
\hline Average & 20 & 50 & 18 & 1185 & 630 & 905 & 555 & 63.05 \\
\hline
\end{tabular}

Table.4 Yield gap green gram variety 'GAM 5' under front-line demonstrations

\begin{tabular}{|c|c|c|c|c|}
\hline Years & Variety & Technology gap & Extension gap & $\begin{array}{c}\text { Technology index } \\
\text { (\%) }\end{array}$ \\
\hline $\mathbf{2 0 1 8}-\mathbf{1 9}$ & (kg/ha) & (kg/ha) & 50.0 \\
\hline $\mathbf{2 0 1 9}-\mathbf{2 0}$ & 'GAM-5' & 900 & 360 & 49.4 \\
\hline Average & - & 890 & 340 & 49.7 \\
\hline
\end{tabular}

Table.5 Economic impact assessment of green gram variety 'GAM 5' under front-line demonstrations

\begin{tabular}{|c|c|c|c|c|c|c|c|c|c|c|}
\hline \multirow[t]{2}{*}{ Year } & \multicolumn{2}{|c|}{$\begin{array}{c}\text { Av.cultivation } \\
\text { cost (Rs/ha) }\end{array}$} & \multirow{2}{*}{$\begin{array}{l}\text { Add. } \\
\text { cost in } \\
\text { FLD's } \\
\text { (Rs/ha) } \\
-\end{array}$} & \multicolumn{2}{|c|}{$\begin{array}{c}\text { Av.gross } \\
\text { returns (Rs/ha) }\end{array}$} & \multicolumn{2}{|c|}{$\begin{array}{l}\text { Av.net returns } \\
\text { (Rs/ha) }\end{array}$} & \multirow{2}{*}{$\begin{array}{c}\text { Add. } \\
\text { returns in } \\
\text { FLD's } \\
\text { (Rs/ha) } \\
-\end{array}$} & \multicolumn{2}{|c|}{ BCR } \\
\hline & FLD's & $\begin{array}{l}\text { Local } \\
\text { check }\end{array}$ & & FLD's & $\begin{array}{l}\text { Local } \\
\text { check }\end{array}$ & FLD's & $\begin{array}{l}\text { Local } \\
\text { check }\end{array}$ & & FLD's & $\begin{array}{l}\text { Local } \\
\text { check }\end{array}$ \\
\hline 2018-19 & 14515 & 12450 & 2065 & $\begin{array}{c}5625 \\
0\end{array}$ & $\begin{array}{c}3375 \\
0\end{array}$ & $\begin{array}{c}4173 \\
5\end{array}$ & $\begin{array}{c}2130 \\
0\end{array}$ & 20435 & 3.87 & 2.71 \\
\hline 2019-20 & 14715 & 12470 & 2245 & $\begin{array}{c}5687 \\
5\end{array}$ & $\begin{array}{c}3562 \\
5\end{array}$ & $\begin{array}{c}4216 \\
0\end{array}$ & $\begin{array}{c}2315 \\
5\end{array}$ & 19005 & 3.86 & 2.85 \\
\hline Average & 14615 & 12460 & 2155 & $\begin{array}{c}5656 \\
3\end{array}$ & $\begin{array}{c}3468 \\
7\end{array}$ & $\begin{array}{c}4194 \\
7\end{array}$ & $\begin{array}{c}2222 \\
7\end{array}$ & 19720 & 3.86 & 2.78 \\
\hline
\end{tabular}

It is concluded that front line demonstrations was an effective tools for increasing the productivity of green gram. The frontline demonstrations conducted on green gram at the farmers' field revealed that the adoption of improved technologies significantly increased the yield as well as yield attributing traits of the crop and also the net returns to the farmers. So, there is a need to disseminate the improved technologies among the farmers with effective extension methods like training. Kisanghosthies, field days, exposure visits and demonstrations. The farmers' should be encouraged to adopt the recommended package of practices realizing for higher returns. This created greater curiosity and motivation among other farmers who do not adopt improved practices of green 
gram cultivation. These demonstrations also built the relationship and confidence between farmers and scientists of KVK. It was also concluded that beside other practices of weed management, insect-past management and water stress to be given due to attention to enhance green gram production in the area. This will subsequently increase the income as well as the livelihood of the farming community of the district.

\section{References}

Chandra, G. (2010). Evaluation of frontline demonstrations of greengram in Sunderban, West Bengal. Journal of Indian Society of Costal Agricultural Research. 28:12-15

Chaudhary, S. (2012). Impact of frontline demonstration on adoption of improved greengram production technology in Nagaur district of Rajasthan. M.Sc. Thesis, SKRAU. Bikaner.

Dayanand, Verma, R.K. and Mahta, S.M. (2012). Boosting the mustard production through front line demonstrations. Indian Research Journal of Extension Education, 12(3):121-123.

Dhaka, B.L., Bairwa, R.K. and Ram, B. (2016).Productivity and profitability analysis of greengram (Cv. RMG 344) at farmer's field in humid southern plain of Rajasthan. Journal of food legume 29(1):71-73.

DOA, (2016).Production and productivity of kharif pulses in Agro-climatic zone of Rajasthan.Pp 122-128.

Gauttam, U.S., Paliwal, D.K. and Singh, S.R.K. (2011). Impact of frontline demonstrations on productivity enhancement of chickpea. Indian Journal of Extension Education, 48 (3\&4): 10-13.

GOR, (2015-16). Vital Agricultural Statistics, Govt. of Rajasthan, Pant KrishiBhawan,
Jaipur. Pp 23-27.

Lothwal, O.P. (2010). Evaluation of front line demonstrations on blackgram in irrigated agro-ecosystem. Annals of Agricultural Research, 31 (1\&3): 24-27.

Math, G., Vijayakumar, A.G., Hegde, Y. and Basamma, K. (2014). Impact of improved technologies on productivity enhancement of sesame (Semmum indicum L.).Indian Journal of Dryland Agricultural Research and Development 29 (2):41-44.

Meena, 0.P., Sharma, K.C., Meena, R. H. and Mitharval, B.S. (2012).Technology transfer through FLDs on mungbean in semi-arid region of Rajasthan. Rajasthan Journal of extension Education, 20:182-186,

Meena, M.L. and Dudi, A. (2012). On farm testing of chickpea cultivars for site specific assessment under rainfed condition of western Rajasthan. Indian Journal of Extension Education. 48 (3\&4): 93-97.

Meena, M.L. and Singh, D. (2016). Productivity enhancement and gap analysis of moth bean (Vigna accontifiilia (Jacq.)) through improved production technologies on farmer's participatory mode. Indian Journal of Dryland Agricultural Research and Development, 31(1):68-71

Meena, M.L. and Singh, D. (2017). Technological and extension yield gaps in greengram in Pali district of Rajasthan, India. Legume Research, 40(1):187-190.

Ofuya, Z.M. and Akhidue.V. (2005). The role of pulses in human nutrition: A review. Journal of Applied Sciences and Environmental Management, 9:99-104.

Poonia, T.C. and Pithia, M.S. (2011).Impact of front line demonstrations on chickpea in Gujarat. Legume Research, 34(4):304-307.

Raj, A.D., Yadav, V. and Rathod, J.H.(2013). 
Impact of front line demonstrations (FLD) on the yield of pulses. International Journal of Scientific and Research, 3(9):1-4

Rajni, Singh, N.P. and Singh, P.(2014). Evaluation of frontline Demonstrations on yield and economic analysis of summer mungbean in Amritsar district of Punjab. Indian Journal of Extension Education. 50 (1\&2):87-89.

Rakhode,P.N. Koche, M.D. and Harne, A.D. (2011). Management of powdery mildew of greengram. Journal of Food Legume, 24(2):120-122.

Singh, B.S. and Chauhan, T.R. (2010).Adoption of mungbean production technology in arid zone of Rajasthan. Indian Research Journal of Extension, 10(2):73-77,

Singh, D. and Meena, M.L. (2011). Boosting seed spices production technology through front line demonstrations.
International Journal of Seed Spices. 1(1):81-85.

Tomar, R.K.S., Sahu, B.L., Singh, R.K. and Prajapati, R.K. (2012). Productivity enhancement of blackgram (Vigna mungoL.) through improved production technologies in farmer's field. Journal of Food Legumes, 22(3):202-204,

Yadav, D.B, Kambhoj, D.K. and Garg, R.B. (2004). Increasing the productivity and profitability of sunflowers through frontline demonstrations in irrigated agro-ecosystem of eastern Haryana. Haryana Journal of Agronomy,20( 1):33-35.

Yadav, V.P.S., Kumar, R., Deshwal, A.K., Raman, R.S., Sharma, B.K. and Bhela, S.L. (2007). Boosting pulse production through frontline demonstration. Indian Journal of Extension Education. $7(2): 12-14$

\section{How to cite this article:}

Manmohan Puniya, M. S. Chandawat, Gajanand Nagal, R. Jeetarwal, B. C. Ola and Arvind Kumar. 2020. Scaling up of Green Gram Production under Front-Line Demonstrations in Jodhpur District of Western Rajasthan, India. Int.J.Curr.Microbiol.App.Sci. 9(01): 1982-1989. doi: https://doi.org/10.20546/ijcmas.2020.901.224 